\title{
LESSONS LEARNED FROM A CANCELLED URBAN TRANSPORT PROJECT IN A DEVELOPING COUNTRY: THE IMPORTANCE OF THE FRONT-END PLANNING PHASE
}

\author{
Seng Hansen ${ }^{1}$, Eric Too ${ }^{1 *}$, Tiendung Le $^{1}$ \\ ${ }^{1}$ School of Property, Construction and Project Management, RMIT University, Melbourne, Victoria \\ 3000, Australia
}

(Received: February 2018 / Revised: March 2018 / Accepted: October 2018)

\begin{abstract}
In many developing countries, infrastructure development has played an important role in driving economic and social growth. It has also been useful in accelerating development at both regional and national levels. Nevertheless, history provides many examples of infrastructure projects that have been cancelled for one reason or another. Such cancellations have often resulted in losses. Thus, it is important to study and learn from these cancelled projects in order to improve future project performance. This paper investigates the case of a cancelled urban transport infrastructure project in Indonesia. The case considered in this study is that of the Jakarta monorail project which was started in 2004 and completely discontinued in 2015 . The example of the Jakarta monorail project is instructive as it has not been the subject of intensive study up to this point. This paper takes a case study approach, coupled with comprehensive reviews of extensive sources on the topic of cancelled infrastructure projects. This study applies a thematic coding technique using NVivo11 software to analyze and find patterns from qualitative data. The observed issues were grouped into three categories, i.e.: the history, causes and impacts of the Jakarta monorail cancellation. Furthermore, the authors also underscore the importance of making a "kill decision" as an option. The findings from this paper also highlight the importance of front-end planning in infrastructure projects.
\end{abstract}

Keywords: Cancelled projects; Front-end planning; Infrastructure; Jakarta Monorail; Lessons learned

\section{INTRODUCTION}

Developing countries invest billions of dollars to build new infrastructure. The result is the development of infrastructure such as transport, power plants, telecommunications, water supply, irrigation, sanitation, etc., all of which are expected to improve people's standard of living. An example can be found in the case of Indonesia, which has invested heavily in infrastructure projects. Increased investment in infrastructure development by the government is expected to stimulate Indonesia's economic growth (Latief et al., 2016; Berawi, 2017).

Unfortunately, the benefits of such investment has not been fully realized, as demonstrated by the numerous failed or cancelled infrastructure projects. This has resulted in significant economic, social and environmental losses due to improper investment planning and utilization, which makes "doing the right project" more important than "doing the project right." Therefore, it is important for organizations to heed the lessons learned from previous projects.

*Corresponding author's email: eric.too@rmit.edu.au, Tel. +61399250192, Fax. +61399252000 Permalink/DOI: https://doi.org/10.14716/ijtech.v9i5.1559 
Organizations in the construction industry should not make repetitive mistakes, especially on such large projects (Caldas et al., 2009).

In light of the historical examples described above, the aim of this paper is to examine the example of a large cancelled infrastructure project in Indonesia and consider the lessons learned from such a case. To achieve this broad aim, this paper addresses two questions. First, why was this large infrastructure project cancelled? Secondly, what can be learned from this cancelled infrastructure project? Consideration of the first question is vital in order to identify the reasons behind this infrastructure project cancellation, while addressing the second question will make it possible to identify the impacts and important lessons learned from the project cancellation.

This paper begins with a review of cancelled infrastructure projects in developing countries and the importance of the lessons learned from these projects. Using one particular case study from Indonesia, this paper presents the causes and impacts of a cancelled infrastructure project. Finally, this paper raises the importance of effective front-end planning to project success.

\section{LITERATURE REVIEW}

\subsection{Abandoned and Cancelled Infrastructure Projects}

The main objectives of construction projects are to complete the project on time, within the specified budget and in accordance with the specified standards of quality. However, it is not uncommon for construction projects to be delayed or even cancelled for various reasons (Hoe, 2013). In Indonesia, perhaps the most well-known example of a cancelled infrastructure projects is that of the Jakarta monorail.

Examples of construction projects being cancelled and then abandoned are not unique to Indonesia. Both developing and developed countries face similar challenges in this regard. Examples can be found in Malaysia (Hoe, 2013; Abdul-Rahman et al., 2015), Spain (Carrero et al., 2009), the United States (Hicks, 2008), Jordan (Al-Hazim et al., 2017), Ghana (Frimpong et al., 2003), Nigeria (Mansfield et al., 1994), Dubai, Abu Dhabi, Saudi Arabia, Qatar, Bahrain, Kuwait, and Russia (SPIEGEL, 2009).

Even though the problem of construction project cancellation is a common one, there is nevertheless a lack of research in this area. Project termination or cancellation is the discontinuation of a project before it achieves its complete implementation (Kumar et al., 1996). A kill decision on a project typically occurs at a major project milestone (Cooper, 2008) or at one of the stage-gate phases. Abdul-Rahman et al. (2015) has noted that an abandoned project occurs when the project is not completed and ready for occupation/use on schedule. Pinto (2013) describes an abandoned project as one which: (1) has been discontinued or cancelled; (2) has failed to deliver on critical specifications; (3) has been completed with significant cost and time overruns; and (4) provides a poor return on investment (ROI). Carrero et al. (2009) focused on the negative impacts of abandoned construction projects on the Spanish coast and its regulation in the law.

Project cancellation is avoided for many reasons, such as project managers' reluctance to terminate a project (Schmidt \& Calantone, 1998), missing perquisites (Kumar et al., 1996), or due to timing difficulties (Tadisina, 1986). Extensive research exists describing the role of decision makers in the project cancellation process (Gomes et al., 2001). The stage of the project and the consequences of cancelling it are important factors that project managers and decision makers must consider when deciding to continue or cancel a project. It may also be difficult for project and decision makers to make decisions because of the "too-much-investedto-quit" syndrome. The literature describes this situation as entrapment, sunk cost effect, or escalation of commitment. Escalation of commitment is described as the "tendency of senior management to mentor their pet projects excessively, thereby allocating more resources than 
justifiable according to strategy or even sticking to a lost cause" (Biyalogorsky et al., 2006). At present, there is no consensus in the literature as to how decision makers make a kill decision (Green et al., 2003). Previous research shows that executives become overly committed (Kessler, 2000) and stick to projects beyond reason (Kirytopoulos et al., 2009).

\subsection{Lessons Learned from Cancelled Infrastructure Projects}

The construction industry is considered to be a leader with regard to economic growth and it is important that the efficiency of practices in this sector be improved (Thomas, 2002). One way to improve practices in this industry is by learning from previous experiences. According to Weber et al. (2000), a "lesson learned" is the result of applying an action which may be positive or negative. Thus, both successes and failures are considered as sources of such lessons. Harrison (2003) describes them as "a good work practice or innovative approach that is captured and shared to promote repeat application, or an adverse work practice or experience that is captured and shared to avoid recurrence." It is used to help organizations to achieve their business needs and goals (Weber et al., 2001). If done effectively, it will become a crucial element in organizations' knowledge management (Caldas et al., 2009).

There are five types of project reviews, i.e. evaluation review, gate review, audit, post-project review, and benefits realization review (APM, 2006). Post-project review is an important project review in which lessons may be learned and used to benefit future projects (Zedtwitz, 2003). It can be done once a project is completed or - as is the case in this study, when a project is terminated. A review will assess overall project success or failure, identify project challenges, as well as the pros and cons of such projects. In addition, Zedtwitz (2003) states that a review should capture lessons from both failed and successful projects. While this research examines Indonesia as a case study, the lessons learned may be of significance to other countries.

\section{METHODS}

The research method used for this study is a case-based approach, coupled with comprehensive reviews from an extensive range of sources related to cancelled infrastructure projects. According to Yin (2003), a case study is used when "a how or why question is being asked about a contemporary set of events, over which the investigator has little or no control." This study involved a five-step process: (1) design of the case study; (2) preparation for data collection; (3) collection of evidence; (4) analysis of data; and (5) reporting on the case study. The first step (case study design) is a phase where the research objective is defined and the case study is planned. This is followed by the second step (i.e. data collection preparation) where procedures and protocols for data collection are established. In this study, the cancellation of the Jakarta Monorail project was the subject (Table 1). It is perhaps the most well-known case of project cancellation in Indonesia.

Table 1 Summary of project

\begin{tabular}{ccccccc}
\hline Project & Sector & Country & $\begin{array}{c}\text { Year of } \\
\text { construction }\end{array}$ & $\begin{array}{c}\text { Year of } \\
\text { cancellation }\end{array}$ & $\begin{array}{c}\text { Year of } \\
\text { revival }\end{array}$ & $\begin{array}{c}\text { Year of } \\
\text { final } \\
\text { termination }\end{array}$ \\
\hline Jakarta Monorail & Railways & Indonesia & 2004 & 2008 & 2013 & 2015 \\
\hline
\end{tabular}

The third step is collection of evidence. In this research, evidence includes media reports, company publications, and government publications, which are reported either in Bahasa Indonesia and English. They are generated using search engines categorized as either academic (e.g. Web of Science TR, RMIT Library Search) or media (e.g. Kompas, Jakarta Post). Some keywords were used to narrow the search, i.e. Jakarta monorail, project cancellation, project abandonment, and front-end planning. In the next step, all evidence from the data collection 
was imported into a powerful qualitative research software tool, QSR International's NVivo11. NVivo is a tool that helps a researcher in organizing, presenting, browsing, coding, annotating, and analyzing data records. This software can improve the process of qualitative research and expand analytical approaches (Auld et al. 2007) as well as the synthesis of ideas (Azeem \& Salfi, 2012). This software was used to manage, explore and find patterns in the research data. Using a thematic coding technique, the authors read all reports and documents, then coded interesting expressions of issues, opinions, problems, phenomena, etc. in the text. As it was coded, the text was evaluated and then grouped into categories (a "node" in NVivo) based on common themes. When some of these categories were found to be similar, they were grouped into a more general category. Finally, the authors used NVivo to establish connections between categories (a "parent node" in NVivo) and their subcategories ("child nodes" in NVivo). Figure 1 (below) shows an example of this coding process conducted using NVivo11.

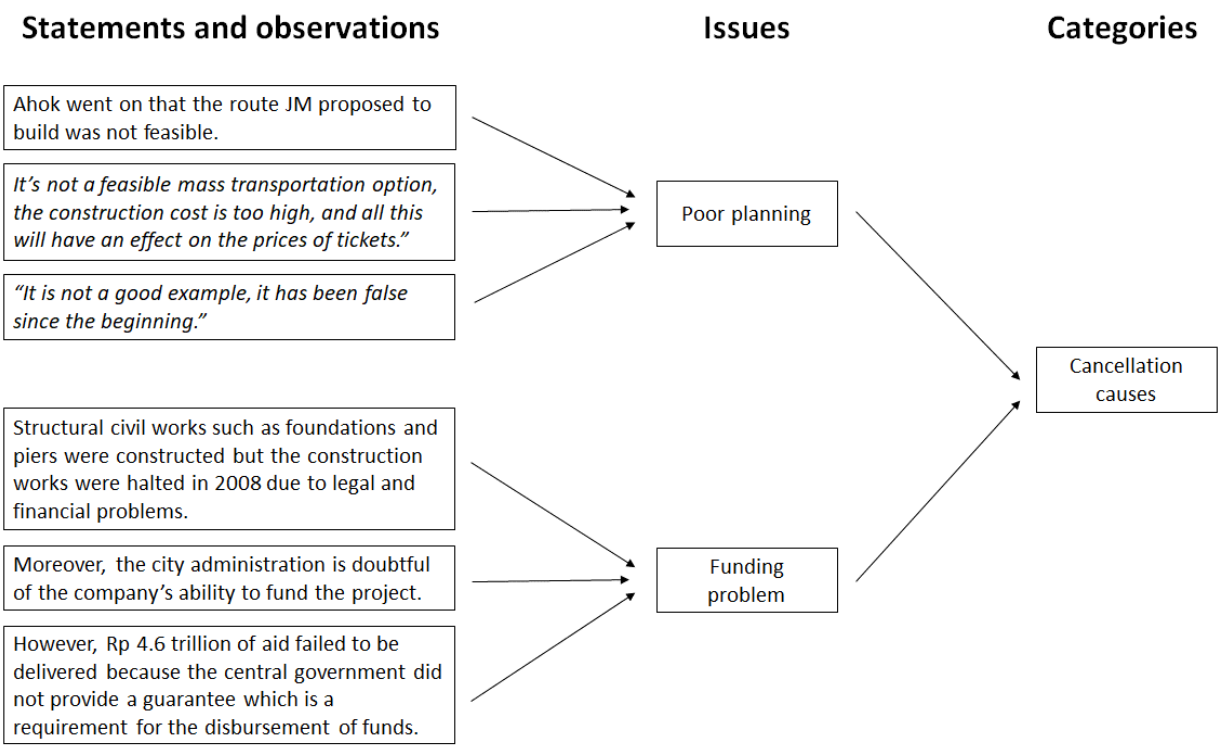

Figure 1 Example of the coding process on cancellation causes

\section{RESULTS AND DISCUSSION}

\subsection{Analyzing the Story of the Jakarta Monorail Project}

The Jakarta monorail is perhaps the most well-known case of a cancelled infrastructure project in Indonesia. It was an urban transport project proposed to address the issue of traffic congestion in Jakarta. The chairman of Ortus Holdings, the majority shareholder of Jakarta Monorail, told reporters: "This will be a part of the solution to solve the city's traffic problems" (Utami \& Moestafa, 2013).

Originally, it would have comprised two lines totaling $29 \mathrm{~km}$ in length (Syatiri, 2013) and circulating the Jakarta CBD. The project had started in 2004 but was then abandoned in 2008 after it failed to obtain funding support. The project was then revived in 2013 (Kuwado, 2013) but was cancelled again in 2015 due to financial problems and legal disputes. The Deputy Governor Basuki Tjahaja Purnama (Ahok) said: "We did everything we could to revive the project. We approved anyone who wanted to build [the monorail]. But if they fail to complete the project, they won't be refunded" (Siregar \& Tambun, 2014).

Later, Ahok criticized continued delays and when he became the Governor of Jakarta in September 2015, he confirmed that the project would not continue, which meant there would be a total discontinuation of this project: "There is no more negotiation; [I] have sent a letter.... There is no more bargaining. We said long ago that the project was over" (Kes, 2015). 
According to him, there were at least 15 requirements proposed by Jakarta city government that were left unfulfilled by the company, including a business plan, a bank guarantee, and the relocation of the depot constructions (Kes, 2015).

This cancellation leaves some unfinished works on site, including the piers and foundation piles. The piers are numerous and it has been proposed that some be used for Jakarta's Light Rail Transit (LRT) project, while others will be demolished. As the Governor Djarot Saiful Hidayat said on August 11, 2017: "Yesterday, I have ordered Adhi Karya to immediately demolish the monorail piers..." (Kurniantoro, 2017).

\subsection{Analyzing the Causes of the Jakarta Monorail Cancellation}

The story of the Jakarta Monorail cancellation provides some lessons for government and private companies who wish to participate in infrastructure projects. The causes of cancellation need to be established and learned from in order to avoid a recurrence of similar mistakes. One of the most significant causes of the Jakarta Monorail cancellation was poor project planning, especially during its front-end planning phase. From the very outset, the project was deemed to be infeasible. According to Deputy Coordinating Ministry of Economy Lucky Eko, the planning phase of the monorail project had been characterized by errors from the very beginning: "It is not a good example, it has been false since the beginning" (Shiddieqy, 2011).

This statement is similar to that from other experts, whom had generally stated that the project was not feasible and was the wrong project to start with. Policy analyst Agus Pambagio had said that the project was far from the ideal mass transportation solution that the city needed; hence, it would not be able to serve its intended purpose. He said: "It's not a feasible mass transportation option, the construction cost is too high, and all this will have an effect on the prices of tickets" (Siregar \& Tambun, 2014). The Chairman of the Transportation Commission of Jakarta's House of Representatives, Selamat Nurdin, pointed out a similar issue and said: "If indeed the is project to be built, it will almost certainly lose money" (Yudhistira, 2014).

An example of poor planning related to the decision-making process included proposed routes which had already been considered infeasible before construction began. According to Ahok, the stations and depot which were to be built in Tanah Abang and Setiabudi would increase traffic congestion in the area: "If JM still wants to develop the monorail system in Jakarta, they must.... They must also propose different routes. The current routes are not feasible" (Wardhani, 2015). The poor planning polemic could also be seen from the statement of the Chairman of Regional Development Planning Agency Jakarta Andi Baso Mappapoleon: "Not yet decided whether it is worth it or not, but at that time, the study was still changing" (Brn, 2014).

Another cause of cancellation was the lack of funding. Construction was first started in 2004. At that time, the composition of the majority shareholder was PT Adhi Karya through PT Indonesia Transit Central (ITC). In just a few weeks, a problem occurred and the project was diverted from ITC to a consortium of PT Jakarta Monorail (JM) and Omnico Singapore. A year later, Omnico failed to meet the deadline of capital payments and so construction was halted. Two years later, the Governor of Jakarta (Sutiyoso) had hoped the development could be continued with funding from several banks from the Middle East. However, IDR 4.6T of aid was not obtained. Once again, the construction of the monorail project was delayed. When Jokowi became Governor of Jakarta, the project was continued. The company was still PT Jakarta Monorail, but the composition of its shareholders had changed. Adhi Karya's share had been diverted to Orthus Infrastructure Capital Ltd (Aws, 2015). According to transportation analyst Izzul Waro, this project has been forced since its beginning. This project could not be well integrated with the MRT project. He said: "If it is the monorail, the demand is small. This 
project has been forced from the beginning. Even if you search to the end of the world, there is no private company who would like to fund the project...." (Brn, 2014).

Other factors that have contributed to the cancellation of this project include delays in progress, bureaucratic problems, inability of parties, poor coordination among stakeholders, and government indecision. According to Ahok, since the time of the ground-breaking ceremony there has been no significant progress on the development of the project. He suspected that JM lacked the necessary funds to complete the work (Siregar \& Tambun, 2014). Summons had been given to JM by the Jakarta House of Representatives, according to member Selamat Nurdin. He had asked JM to provide explanations as to why the project had not made any significant progress: "This is our complaint: the council has summoned the management twice last year, but they have never showed up" (Purnamasari \& Tambun, 2014). As a result of the delay, Ahok has considered offering an ultimatum to the company : "If [Jakarta Monorail] is unable to continue the project, we will revoke [their license]" (Purnamasari \& Tambun, 2014).

Meanwhile, according to the JM company, bureaucracy has been the cause of project delays. Jakarta Monorail Technical Director Bovananto has said that the company needed more time to resolve all of the project's legal, administrative and technical matters, indicating that the project delay was due to outstanding documents (Ian, 2013). Another JM director, Sukmawati, has commented that: "... Our main obstacle is that we do not have the support of the governor or the bureaucracy..." (Wardhani, 2015).

However, a different argument has been presented by Ahok. He has said that one of the reasons for the project cancellation is the JM company's inability to meet the city's proposed requirements. According to him, there were at least 15 requirements left unfulfilled by the company (Kes, 2015). This indicates poor coordination between government and the developer as project stakeholders. In fact, poor project coordination was considered by Hatta Rajasa (the Coordinating Minister for Economy) as one of the main causes of cancellation (Zul, 2012).

On the other hand, spatial analyst Nirwono Joga has said that government indecision is one of the main causes of project cancellation (Kusuma, 2015). The project had been started in 2004 and since that time there had been four changes of governor, yet only the last governor has made a bold decision in relation to the fate of the Jakarta monorail. This indicates that government assertiveness is needed with regard to the sustainability of a project, and this is especially so in the case of infrastructure projects.

Of the seven causes of cancellation explored above, poor front-end planning has become the main cause that is most frequently cited by the parties involved in project planning and implementation. This demonstrates the importance of adequate front-end planning in the development of a large-scale construction project. Appropriate front-end has been identified as an important factor affecting the project success rate (Hwang \& Ho, 2012), while inadequate front-end planning will lead to poor project performance (Oh et al., 2016). Another example of a failed project cancelled due to poor front-end planning is that of the Cilamaya Port project in Karawang. An incomplete technical study (as well as safety issue) were the main causes of the cancellation (Hansen, 2018).

\subsection{Examining the Impacts of the Jakarta Monorail Cancellation}

The cancellation of the Jakarta Monorail has had negative impacts on the economy and society. Firstly, the cancellation has resulted in a waste of resources and loss of opportunities to benefit from the project, as noted by Pakuwon Group Director Stefanus Ridwan. He has said that if there is no clear realization of the Jakarta Monorail development, the losses would be much greater than the cost of the project's investment as there are many new developments that would be carried out in the regions surrounding the monorail routes. He has said: "Our project, Casablanca City for example, we have already experienced the operational costs of the 
Casablanca City Phase II project, which includes the reserve fund to cover the "losses" caused by the monorail project if it is built simultaneously" (Alexander, 2014).

Furthermore, he has explained that the reserves fund could be allocated to other project investments. In addition, Ridwan explains that there has been a loss of momentum with respect to realizing profits from other opportunities that could have arisen had the monorail project succeeded. He has also noted the impact that the monorail cancellation has had on society: "Not only that, [this cancellation] will cause greater loss to the people of Jakarta. The social cost is too high if the monorail is cancelled. Jakarta's congestion will not find a solution" (Alexander, 2014).

Another significant impact of this cancellation is the urban spatial mess created from the unfinished piers and piles in the Kuningan-Karet-Sudirman area, also known as the Golden Triangle area. Spatial analyst Nirwono Joga has said that the ones who will suffer most from this mega-project are the citizens of Jakarta, as they must contend with an urban spatial layout (e.g. roads) that is becoming increasingly narrow and jammed (Kusuma, 2015).

Lastly, this cancellation has had consequences which now pose a danger to the public and have contributed to several accidents. The monorail piers and piles were left untouched on-site. According to a reporter's observation of the site, there are many pieces of rebar from piles and piers left standing between the sidewalks and this poses a danger to pedestrians. Notably, there remains a pile left in the middle of one road that continues to endanger road users (Aco, 2012).

\subsection{Making the "Kill Decision": When Project Cancellation Becomes an Option}

Making a kill decision on an individual project requires courage and the consideration of many factors. Making such a decision is challenging for project managers, especially in situations where there has been an escalation of commitment. The Jakarta Monorail project has become one of the rare examples of a problematic kill decision which has led to multiple subsequent project cancellations. It was first cancelled in 2008. Several revival efforts were made in 2013, which eventually incurred additional costs. In 2015, the project was totally abandoned, leaving incomplete works on-site. Thus, this project represents a good example of how executives can become unjustifiably committed to a project. In light of the reasons and examples described in this paper, the option of cancelling a project may be appropriate in order to avoid further losses

According to Hoe (2013), a construction project may be cancelled at any stage of the project lifecycle. This is usually arranged in a construction contract that stipulates a special clause regarding project termination. However, it must be remembered that the termination of a construction project will surely incur some significant consequences. It is important to note that all project deliverables are assets that will disappear if not carefully managed. This has been a long-standing problem and deserves more attention.

Therefore, it is important for all project participants to monitor and control an on-going project. If, realistically, the project is not going to achieve its objective or is not progressing well enough, making a kill decision may be a reasonable option. The kill decision is not an easy one, as it requires consideration of many factors. Once a project is cancelled or terminated, it needs to be totally discontinued so as not to affect the overall portfolio strategy of stakeholders (Unger et al., 2012). However, a problem associated with the kill decision is the absence of a mechanism to kill unperformed projects and the absence of established criteria for making killand prioritization-decisions (Cooper et al., 2002). Thus, it is important to have "critical" kill decision points or criteria built into a project, in the form of procedures or regulations. 


\section{CONCLUSION}

In most developing countries, it has become apparent that the project planning process is prone to a number of procedural weaknesses which has made the successful execution of a project difficult. Adequate front-end planning plays a vital role in the improvement of project performance. Therefore, it is very important for government and other stakeholders to devote sufficient resources to the front-end planning phase of infrastructure projects. Using the cancellation of the Jakarta monorail as a case study, this paper has identified seven cancellation causes and four cancellation impacts. This project has also become an exemplary case where poor project planning-particularly during the front-end planning phase, will lead to poor project performance. This case illustrates several key lessons:

1. It is crucial that a project have adequate front-end planning (FEP). Prior to starting any urban transport infrastructure project, government must undertake a feasibility study to fully understand the project's funding requirements and other key issues related to the project's financials, including the mechanism for private sector participation.

2. Since urban transport infrastructure is a public good, government must control and monitor the ongoing projects. Assertiveness on the part of government is required to ensure the viability of ongoing infrastructure projects.

3. Whenever decision makers feel it is necessary to cancel a project, the decision needs to be made quickly and decisively. Once it is cancelled, the project needs to be completely discontinued. Therefore, it is important that when making a kill decision, decision makers have considered all the reasons and consequences for doing so. Revival efforts can only be attempted if the project's FEP phase has been thoroughly reviewed. Otherwise, further losses are likely to be incurred. A project cancellation procedure may be needed to regulate such situations.

The contribution of this paper is two-fold. First, it establishes some lessons learned from the example of a cancelled large infrastructure project in Indonesia, one which has rarely been studied before. Second, this study shows that by learning from previous experience, decision makers and project teams can create a suitable environment for project success through adequate front-end planning. This study therefore highlights the importance of the front-end planning phase in infrastructure project development.

\section{ACKNOWLEDGEMENT}

The authors would like to express their gratitude to RMIT University, Agung Podomoro University and Lembaga Pengelola Dana Pendidikan (LPDP) for supporting this research. Grant Number: PRJ-4114/LPL.3/2016.

\section{REFERENCES}

Abdul-Rahman, H., Wang, C., Ariffin, N.H., 2015. Identification of Risks Pertaining to Abandoned Housing Projects in Malaysia. Journal of Construction Engineering, Volume 2015, pp. 1-12

Aco, H., 2012. Bekas Tiang Pancang Monorel Jakarta Jadi Ranjau Darat (Former Pole of Jakarta Monorail Becomes Landmine). Tribun News. Available online at http://www.tribunnews.com/metropolitan/2012/09/13/bekas-tiang-pancang-monoreljakarta-jadi-ranjau-darat., Accessed on November 13, 2017

Al-Hazim, N., Salem, Z.A., Ahmad, H., 2017. Delay and Cost Overrun in Infrastructure Projects in Jordan. Procedia Engineering, Volume 182, pp. 18-24

Alexander, H.B., 2014. Jika Monorel Batal, Pengembang Rugi Besar (If Monorail Cancelled, A Big Loss for Developer). Kompas. Available online at 
http://properti.kompas.com/read/2014/02/18/2101245/.Jika.Monorel.Batal.Pengembang.Ru gi.Besar, Accessed on November 15, 2017

APM, 2006. APM Body of Knowledge 5th Edition. Association for Project Management, UK: Princes Risborough

Auld, G.W., Boushey, C.J., Cluskey, M., Misner, S.L., Wang, C., 2007. Development of a Decision Tree to Determine Appropriateness of NVivo in Analyzing Qualitative Data Sets. Journal of Nutrition Education and Behavior, Volume 39(1), pp. 37-47

Aws., 2015. Perjalanan Panjang Pencanganan Monorel di DKI Hingga Akhirnya Mangkrak (Long Journey of Declaration of Monorail in DKI until Finally Stalled). Detik News. Available online at https://news.detik.com/berita/2802635/perjalanan-panjangpencanangan-monorel-di-dki-hingga-akhirnya-mangkrak\#, Accessed on November 14, 2017

Azeem, M., Salfi, N.A., 2012. Usage of NVivo Software for Qualitative Data Analysis. Academic Research International, Volume 2(1), pp. 262-266

Berawi, M.A., 2017. Fostering Partnerships and Strategic Alliances in Sustainable Infrastructure Development. International Journal of Technology, Volume 8(4), pp. 568571

Biyalogorsky, E., Boulding, W., Staelin, R., 2006. Stuck in the Past: Why Managers Persist with New Product Failures. Journal of Marketing, Volume 70(2), pp. 108-121

Brn., 2014. Sejak Awal Proyek Monorel Sudah Dipaksakan (The Monorail Project has been Forced since the Beginning). Detik News. Available online at https://news.detik.com/berita/d-2509250/sejak-awal-proyek-monorel-sudah-dipaksakan,

Accessed on November 14, 2017

Caldas, C.H., Gibson, G.E., Weerasooriya, R., Yohe, A.M., 2009. Identification of Effective Management Practices and Technologies for Lessons Learned Programs in the Construction Industry. Journal of Construction Engineering and Management, Volume 135(6), pp. 531-539

Carrero, R., Malvarez, G., Navas, F., Tejada, M., 2009. Negative Impacts of Abandoned Urbanization Projects in the Spanish Coast and Its Regulation in the Law. Journal of Coastal Research, Volume SI 56, pp. 1120-1124

Cooper, R.G., 2008. Perspective: The Stage-Gate® Idea-to-Launch Process-Update, What's New, and NexGen Systems. Journal of Product Innovation Management, Volume 25(3), pp. 213-232

Cooper, R.G., Edgett, S.J., Kleinschmidt, E.J., 2002. Optimizing the Stage-gate Process: What Best Practice Companies are Doing - Part Two. Product Development Institute Inc. Available online at http://stage-gate.net/downloads/working_papers/wp_15.pdf

Frimpong, Y., Oluwoye, J., Crawford, L., 2003. Causes of Delay and Cost Overruns in Construction of Groundwater Projects in Developing Countries: Ghana as a Case Study. International Journal of Project Management, Volume 21(5), pp. 321-326

Gomes, J., De Weerd-Nederhof, P., Pearson, A., Fisscher, O., 2001. Senior Management Support in the New Product Development Process. Creativity \& Innovation Management, Volume 10(4), pp. 234-242

Green, S.G., Welsh, M.A., Dehler, G.E., 2003. Advocacy, Performance, and Threshold Influences on Decisions to Terminate New Product Development. Academy of Management Journal, Volume 46(4), pp. 419-434

Hansen, S., 2018. Implementation of PDRI during Front-end Planning: A Strategy to Improve Indonesia's Maritime Infrastructure Project Performance. In: Indonesian Global Scholars Forum (IGSF) Conference 23-25 February 2018, Perth, Australia, pp. 1-16 
Harrison, W., 2003. A Software Engineering Lessons Learned Repository. In: Proceeding of the $27^{\text {th }}$ Annual NASA Goddard/IEEE Software Engineering Workshop, Institute of Electrical and Electronics Engineers, Los Alamitos, California

Hicks, M., 2008. United States, Real Estate, Contract, Project Abandonment: Separate Legal Concepts. Mondaq. Available online at http://www.mondaq.com/unitedstates/x/60362/Building+ Construction/ Contract+Project+Abandonment+Separate+Legal+Concepts, Accessed on October 5, 2017

Hoe, Y.E., 2013. Causes of Abandoned Construction Projects in Malaysia. Master Thesis, Universiti Tunku Abdul Rahman

Hwang, B.G., Ho, J.W., 2012. Front-end Planning Implementation in Singapore: Status, Importance, and Impact. Journal of Construction Engineering and Management, Volume 138(4), pp. 567-573

Ian, 2013. Bureaucracy Delays Monorail Project. The Jakarta Post. Available online at http://www.thejakartapost.com/news/2013/06/20/bureaucracy-delays-monorailproject.html, Accessed on November 5, 2017

Kes, 2015. Ahok Confirms Cancellation of Monorail Project. The Jakarta Post. Available online at http://www.thejakartapost.com/news/2015/09/10/ahok-confirms-cancellation-monorailproject.html, Accessed on November 3, 2017

Kessler, E.H., 2000. Tightening the Belt: Methods for Reducing Development Costs Associated with New Product Innovation. Journal of Engineering and Technology Management, Volume 17(1), pp. 59-92

Kirytopoulos, K., Voulgaridou, D., Panopoulos, D., 2009. Project Termination Analysis in SMEs: Making the Right Call. International Journal of Management and Decision Making, Volume 10 (1/2), pp. 69-90

Kumar, V., Persaud, A.N.S., Kumar, U., 1996. To Terminate or Not an Ongoing R\&D Project: A Managerial Dilemma. IEEE Transactions on Engineering Management, Volume 43(3), pp. 273-284

Kurniantoro, Y.C., 2017. Bekas Tiang Pancang 'Monorail' Akan Dibongkar (The Former Monorail Pile will be Demolished). Netral News. Available online at http://www.netralnews.com/news/megapolitan/read/94222/bekas.tiang.pancang....monorail .....akan, Accessed on November 12, 2017

Kusuma, H., 2015. Tindak Tegas, Tata Ruang Jakarta Rusak Akibat Proyek Monorel (Firm Action, Jakarta Spatial Damage Caused by Monorail Project). Okezone. Available online at https://economy.okezone.com/read/2015/01/15/320/1092886/tindak-tegas-tata-ruangjakarta-rusak-akibat-proyek-monorel, Accessed on November 12, 2017

Kuwado, F.J., 2013. Jokowi Pastikan Proyek Monorel Dilanjutkan (Jokowi Ensures the Monorail Project is Continued.). Kompas. Available online at https://megapolitan.kompas.com/read/2013/06/26/1453496/Jokowi.Pastikan.Proyek.Monor el.Dilanjutkan, Accessed on October 5, 2017

Latief, Y., Berawi, M.A., Rarasati, A.D., Supriadi, L.S., Berawi, A.R.B., Hayuningtiyas, I.S., 2016. Mapping Priorities for the Development of the Transportation Infrastructure in the Provincial Capitals of Indonesia. International Journal of Technology, Volume 7(4), pp. 544-552

Mansfield, N.R., Ugwu, O.O., Doran, T., 1994. Causes of Delay and Cost Overruns in Nigerian Construction Projects. International Journal of Project Management, Volume 12(4), pp. 254-260

Oh, E.H., Naderpajouh, N., Hastak, M., Gokhale, S., 2016. Integration of the Construction Knowledge and Expertise in Front-end Planning. Journal of Construction Engineering and Management, Volume 142(2), pp. 04015067-1-04015067-12 
Pinto, J.K., 2013. Lies, Damned Lies, and Project Plans: Recurring Human Errors That Can Ruin the Project Planning Process. Business Horizons, Volume 56(5), pp. 643-653

Purnamasari, D.M., Tambun, L.T., 2014. Basuki Threatens to Stop Monorail Project If Progress Isn't Made. Jakarta Globe. Available online at http://jakartaglobe.id/news/basuki-threatensto-stop-monorail-project-if-progress-isnt-made/, Accessed on November 13, 2017

Schmidt, J.B., Calantone, R.J., 1998. Are Really New Product Development Projects Harder to Shut Down? Journal of Product Innovation Management, Volume 15(2), pp. 111-123

Shiddieqy, M.I., 2011. Sejak Awal Perencanaan Proyek Monorail Terdapat Kesalahan (Since the Beginning, There is a Mistake in Planning of the Monorail Project). Republika. Available online at http://www.republika.co.id/berita/nasional/umum/11/06/14/lms1v4sejak-awal-perencanaan-proyek-monorail-terdapat-kesalahan, Accessed on November 11, 2017

Siregar, H., Tambun, L.T., 2014. Jakarta Could Take Over Monorail Project if Delays Continue: Basuki. Jakarta Globe. Available online at http://jakartaglobe.id/jakarta/jakartacould-take-over-monorail-projectif-delays-continue-basuki/, Accessed on November 12, 2017

SPIEGEL, 2009. Architecture's Reality Check: Global Downturn Dooms Prestige Construction Projects. SPIEGEL ONLINE International. Available online at: http://www.spiegel.de/international/business/architecture-s-reality-check-global-downturndooms-prestige-construction-projects-a-601523.html, Accessed on October 20, 2017

Syatiri, A.S., 2013. Pembangunan Monorel Dilanjutkan, Mohon Bersabar (Monorail Construction Continued, Please be Patient). Kompas. Available online at http://megapolitan.kompas.com/read/2013/10/16/1025199/Pembangunan.Monorel.Dilanjut kan.Mohon.Bersabar, Accessed on October 30, 2017

Tadisina, S.K., 1986. Support System for the Termination Decision in R \& D Management. Project Management Journal, Volume 17(5), pp. 97104

Thomas, H.R., 2002. 2000 Peurifoy Lecture: Construction Practices in Developing Countries. Journal of Construction Engineering and Management, Volume 128(1), pp. 1-7

Unger, B.N., Kock, A., Gemünden, H.G., Jonas, D., 2012. Enforcing Strategic Fit of Project Portfolios by Project Termination: An Empirical Study on Senior Management Involvement. International Journal of Project Management, Volume 30(6), pp. 675-685

Utami, W., Moestafa, B., 2013. Jakarta Starts Monorail Project after Five-Year Pause. Jakarta Globe. Available online at http://jakartaglobe.id/news/jakarta/jakarta-starts-monorailproject-after-five-year-pause/, Accessed on November 12, 2017

Wardhani, D.A., 2015. Jakarta to Cancel Monorail Construction. The Jakarta Post. Available online at http://www.thejakartapost.com/news/2015/01/13/jakarta-cancel-monorailconstruction.html, Accessed on November, 152017

Weber, R., Aha, D.W., Becerra-Fernandez, I., 2001. Intelligent Lessons Learned Systems. Expert Systems with Applications, Volume 20(1), pp. 17-34

Weber, R., Aha, D.W., Muñoz-Avila, H., Breslow, L.A., 2000. An Intelligent Lessons Learned Process. In Z. W. Ras \& S. Ohsuga (Eds.), Foundations of Intelligent Systems: Proceedings of the Twelfth International Symposium (ISMIS 2000); LNAI 1932 (pp. 358-367). Berlin: Springer

Yin, R.K., 2003. Case Study Research: Design and Methods $3^{\text {rd }}$ Edition. Sage Publications, Inc., California

Yudhistira, A., 2014. DPRD: Monorel Dibangun, Insya Allah Rugi! (DPRD: Monorail Built, God Willing, Loss) Okezone News. Available online at https://news.okezone.com/read/2014/02/20/500/944029/dprd-monorel-dibangun-insyaallah-rugi, Accessed on November 15, 2017 
Zedtwitz, M. von, 2003. Post-Project Reviews in R\&D. Research-Technology Management Volume 46(5), pp. 43-49

Zul, 2012. Ini Alasan Hatta Soal Proyek Monorel Jakarta Gagal Dibangun (This is Hatta's Reason for the Jakarta Monorail Project Failed to be Built). Detik Finance. Available online at https://finance.detik.com/berita-ekonomi-bisnis/2007396/ini-alasan-hatta-soalproyek-monorel-jakarta-gagal-dibangun, Accessed on November 14, 2017 